\title{
PERILAKU TECHNOPRENEUR MAHASISWA TEKNIK INFORMATIKA: TINJAUAN PADA SELF-SUFFICIENCY
}

\author{
Oleh: \\ Yusmedi Nurfaizal \\ Mahasiswa Doktor Ilmu Manajemen Universitas Jenderal Soedirman \\ Purwokerto
}

\begin{abstract}
Abstrak
Sebuah pendekatan pendidikan baru untuk pembangunan berkelanjutan yang muncul dalam literatur kewirausahaan. Artikel ini menyesuaikan teori perilaku yang direncanakan untuk memeriksa sikap terhadap bentuk kewirausahaanyang dilakukan mahasiswa. Artikel ini bertujuan menilai perilaku technopreneur mahasiswa teknik informatika dari self-suffiency serta untuk mengetahui korelasi antara karakteristik demografi dengan self-suffiency. Jenis kelamin mempunyai korelasi yang signifikan dengan self-suffiency, sedangkan penghasilan, status tinggal dan usia tidak mempunyai korelasi yang signifikan dengan self-suffiency. Hasil ini ada yang konsisten dengan temuan sebelumnya dan ada pula yang tidak selaras. Oleh karena itu dapat ditindaklanjuti oleh peneliti selanjutnya. Hal ini menunjukkan pentingnya menyoroti manfaat kewirausahaan yang berkelanjutan untuk merangsang minat lebih dalam pembangunan berkelanjutan. Kontribusi utama dari studi ini adalah bahwa lembaga pendidikan perlu menyediakan program keberlanjutan memberikan kesempatanuntuk mendorong pengusaha yang baru lahir.
\end{abstract}

Kata kunci

Perilaku, technopreneur, karakteristik demografi, self-suffiency

\section{PENDAHULUAN}

Undang-Undang Nomor 20 Tahun 2003 tentang Sistem Pendidikan Nasional pada Pasal 1 ayat 1 bahwa pendidikan adalah usaha sadar dan terencana untuk mewujudkan suasana belajar dan proses pembelajaran agar peserta didik secara aktif mengembangkan potensi dirinya untuk memiliki kekuatan spiritual keagamaan, pengendalian diri, kepribadian, kecerdasan, akhlak mulia, serta keterampilan yang diperlukan dirinya, masyarakat, bangsa dan negara . Dengan demikian pembangunan pendidikan pada umumnya dan pendidikan di jenjang perguruan tinggi merupakan salah satu wahana dan sekaligus cara untuk membangun manusia, baik sebagai insan, maupun sebagai sumber daya pembangunan, terutama dalam memasuki Masyarakat Ekonomi Asia (MEA).

Untuk mengatasi tantangan globalisasi, tidak ada cara yang paling ampuh, kecuali meningkatkan daya saing bangsa. Kenyataan yang dihadapi saat ini adalah bahwa, daya saing bangsa Indonesia masih lemah. Hal-hal yang mempengaruhi rendahnya daya saing tersebut, diantaranya adalah rendahnya kemampuan manajemen dan kedua rendahnya kemampuan dalam bidang IPTEK, serta rendahnya kualitas sumber daya manusia. Untuk 
itu diperlukan perubahan yang meningkatkan dalam bidang pendidikan, yang menjadi salah satu upaya menyiapkan SDM yang berkualitas.

Situasi ketenagakerjaan di Indonesia masih ditandai dengan tingginya tingkat pengangguran terbuka dan masih lambatnya daya serap tenaga kerja di lapangan kerja formal. Jumlah setengah pengangguran yang cukup besar juga mencerminkan lapangan kerja pada sektor yang digelutinya menjadi kurang produktif yang menyebabkan mereka berpendapatan rendah. Rendahnya produktivitas dan pendapatan menjadi sumber utama yang menyebabkan mereka sebagian besar berada di bawah garis kemiskinan. Untuk itu upaya menciptakan lapangan kerja baru menjadi prioritas utama pemerintah.

Pertumbuhan jumlah entrepreneur selama tiga tahun terakhir berdasarkan data dari Kementerian Koperasi dan Usaha Kecil dan Menengah Republik Indonesia Tahun 2012menunjukkan laju pertumbuhan yang cepat dari $0,18 \%$ pada tahun $2010,0,56 \%$ pada tahun 2011 dan pada tahun 2012 meningkat drastis menjadi $1,56 \%$, tetapi laju pertumbuhan tersebut masih berada dibawah angka ideal yaitu 2\%.Pemerintah mulai menggalakkan penyuluhan tentang kewirausahaan bagi masyarakat di media cetak maupun media elektronik. Pada 29 Oktober 2009 Presiden Susilo Bambang Yudhoyono di depan 1.500 stakeholders Indonesia dalam acara Rembuk Nasional (National Summit) menyatakan bahwa ada tiga strategi utama yang harus dilakukan Indonesia, yaitu pemberdayaan, kewirausahaan, dan inovasi teknologi. Karena ada program pemerintah itu, negara mulai menggalakkan dan menyebarkan pengetahuan tentang kewirausahaan secara lebih luas. Dari mulai sekolah menengah, hingga perguruan tinggi menjadi sasaran untuk memberikan motivasi dan pengetahuan tentang pentingnya berwirausaha. Hal ini bertujuan agar saat mereka lulus dan terjun langsung ke masyarakat, mereka memiliki cukup ilmu dan mental menjadi seorang entrepreneur. Mereka tidak lagi canggung untuk menghadapi dunia bisnis maupun pekerjaan yang sulit didapatkan.

Entrepreneurship untuk bidang teknologi memiliki istilah technopreneurship dimana didalamnya terdapat karakteristik yang spesifik untuk bidang teknologi, yaitu skill yang tinggi dibidang technology, kreatif, inovatif, dinamis, berani tampil beda dan selalu mencoba untuk mendefinisikan ulang ekonomi digital yang sifatnya dinamis. Pengertian technopreneurship sendiri menurut Sutabri (2009) merupakan proses dan pembentukan usaha baru yang melibatkan teknologi sebagai basisnya, dengan harapan bahwa penciptaan strategi dan inovasi yang tepat kelak bisa menempatkan teknologi sebagai salah satu faktor untuk pengembangan ekonomi nasional.

Selama beberapa dekade sekarang, semakin banyak penelitian telah menetapkan kontribusi penting kewirausahaan dalam pertumbuhan ekonomi dan pembangunan (Baumol et al, 2007; Gries dan Naude, 2008; Naude, 2008; Shramm, 2004). Wennekers et al. (2005), Van Stel et al. (2005), Acs dan Varga (2005), Wong et al. (2005), Rocha dan Sternberg (2005), Anokhin dan Schulze (2009), Frederick dan Monsen (2011), Hessels dan Van Stel (2011) dan Koellinger dan Thurik (2012) semua menemukan bukti adanya hubungan antara tingkat kegiatan kewirausahaan dan 
pertumbuhan ekonomi dan dengan menggunakan berbagai pembangunan.

Shane, (2003) menyatakan bahwa karakteristik individu, wirausaha dapat dibedakan berdasarkan faktor demografis seperti umur, jenis kelamin, status sosial, dan pendidikan. Kedua faktor psikologis seperti motivasi, kepribadian, dan proses kognitif. Berbagai studi kewirausahaan telah dilakukan untuk mengetahui pengaruh faktor-faktor individual seperti karakteristik kepribadian (Nishanta, 2008), karakteristik psikologis (Jung dkk, 2001; Boyd \& Vozikis, 1994), demografis (Nishanta, 2008; Gerry dkk, 2008), Saraf(2015) menemukan bahwa pengalaman kerja paruh waktu dan jaringan sosial efek adalah yang terkuat dalam membentuk niat kewirausahaan. Sebuah hasil yang mencolok terlihat dalam kasus gender, yang menunjukkan tidak ada dampak yang signifikan terhadap kemungkinan memulai bisnis, menunjukkan bahwa pria dan wanita sama-sama cenderung memiliki niat kewirausahaan.

Penelitian ini bertujuan untuk mengkajipengaruh faktor individual terhadap intensiuntuk mengembangkan usaha dengan subyek mahasiswa teknik informatikan. Pemahaman atas faktor yang mempengaruhi pertumbuhan technopreneur akan bermanfaat bagi para pengambil kebijakan dan pihakpihak yang berkepentingan dalam merumuskan program yang sesuai untuk pengembangan usaha mikro yang efektif dan berkelanjutan. Di samping itu, hasil penelitian ini dapatmemperkuat teori technopreneur pada level individual khususnya yang terkaitdengan pengembangan usaha mikro.

Tujuan dari penelitian ini adalah untuk menguji kemandirian dan perilaku mahasiswa teknik informatika terhadap minat technopreneurship

\section{KERANGKA TEORITIS DAN PENGEMBANGAN HIPOTESIS}

1. Kerangka Teoritis

a. Perilaku Technopreneur

Technopreneurship merupakan istilah bentukan dari dua kata, yakni teknologi dan enterpreneurship . Secara umum, kata Teknologi digunakan untuk merujuk pada penerapan praktis ilmu pengetahuan ke dunia industri atau sebagai kerangka pengetahuan yang digunakan untuk menciptakan alat-alat, untuk mengembangkan keahlian dan mengekstraksi materi guna memecahkan persoalan yang ada. Sedangkan kata Entrepreneurship berasal dari kata Entrepreneur yang merujuk pada seseorang atau agen yang menciptakan bisnis/usaha dengan keberanian menanggung resiko dan ketidakpastian untuk mencapai keuntungan dan pertumbuhan dengan cara mengidentifikasi peluang yang ada (Zimmerer \& Scarborough, 2008). Jika kedua kata diatas digabungkan, maka kata teknologi disini mengalami penyempitan arti, karena Teknologi dalam Technopreneurship mengacu pada Teknologi Informasi, yakni teknologi yang menggunakan Komputer sebagai alat pemrosesan.

Badan Pengkajian dan Penerapan Teknologi, (2010) mendefinisikan bahwa technopreneur adalah gabungan dari kata technique dan entrepreneur yang artinya adalah orang yang mempunyai skill di bidang teknologi namun dapat membaca peluang usaha 
di bidang teknologi. Technopreneur secara sederhana dapat diartikan sebagai seorang peminat teknologi yang berjiwa entrepreneur. Dapat juga diartikan bahwa technopreneuradalah pengusaha yang membangun bisnisnya berdasarkan keahliannya di bidang ilmu pengetahuan dan teknologi, dan menghasilkan produk inovatif yang berguna tidak hanya bagi dirinya, tetapi bagi kesejahteraan bangsa dan negaranya. Technopreneur berbeda dengan enterpreneur. Bila enterpreneur didefinisikan sebagai seorang yang mengordinasikan, memanajemen, dan mengambil resiko dari suatu bisnis, maka technopreneur didefinisikan sebagai seorang enterpreneur yang dalam bisnisnya melibatkan teknologi.

Soeryanto (2009) Technopreneurship (teknologi merupakan Entepreneurship) Entrepreneurship yang menekankan pada faktor teknologi yaitu kemampuan ilmu pengetahuan dan teknologi dalam proses bisnisnya.

Technopreneurship merupakan wirausaha yang kreatif dan inovatif dalam memanfaatkan dan mengabungkan teknologi sehingga menghasilkan suatu produk atau jasa mereka akan bertanggung jawab segala risiko yang akan terjadi. Seorang Technopreneurship akan jeli dalam melihat suatu peluang dan kesempatan yang ada disekitarnya.

b. Karakteristik Demografi

Siagian (2008) menyatakan bahwa, karakteristik biografikal (individu) dapat dilihat dari umur, jenis kelamin, status perkawinan, jumlah tanggungan dan masa kerja. Sedangkan Notoatmodjo (2010) menyebutkan ciriciri individu digolongkan kedalam tiga kelompok yaitu 1) Ciri-ciri demografi, seperti jenis kelamin dan umur, 2) Struktur sosial, seperti tingkat pendidikan, pekerjaan, kesukuan atau ras, dan sebagainya, 3) Manfaatmanfaat kesehatan, seperti keyakinan bahwa pelayanan kesehatan dapat menolong proses penyembuhan penyakit. Bogue (1969) menyatakan bahwa demografi adalah ilmu yang mempelajari secara statistika dan matematika tentang besar, komposisi, dan distribusi penduduk serta perubahan-perubahannya sepanjang masa melalui bekerjanya 5 komponen demografi yaitu kelahiran, kematian, perkawinan, migrasi dan mobilitas sosial.

\section{c. Self-Suffiency}

Hong et.al (2009) menyarankanbahwa self sufficiency adalah proses pengembangan kekuatan psikologis. Vohs, dan Mead (2008), menyatakan self sufficiency adalah penekanan padaperilaku yang dipilih oleh individu yang dapat dicapai tanpa keterlibatan aktif dariorang lain. Seymour (n.d), menyatakan bahwa self sufficiency kecukupan atas sesuatuyang dimiliki dan berjuang untuk standar hidup yang lebih tinggi, termasukmakanan, lingkungan, kesehatan, dan pekerjaan.Konsep ini tidak hanya mencakup pengertian kecukupan diri (self-sufficiency) di bidangekonomi, tetapi juga meliputi faktor manusia secara pribadi, yang di dalamnyamengandung unsur penemuan diri (self-discovery) berdasarkan kepercayaan diri (selfconfidence).

Kemandirian adalah satu sikap yang mengutamakan kemampuan dirisendiri dalam mengatasi pelbagai masalah demi mencapai satu tujuan, tanpa menutupdiri terhadap pelbagai kemungkinan kerjasama yang saling menguntungkan (Ismawan, 2003). Penelitian Taylor, Gross, Roese (2015) membangun penelitian sebelumnya yang meneliti identitas petugas sosial dan manajemen kasus (Watkins-Hayes, 
2009) dengan menyelidiki bagaimana para manajer melihat tantangan dan hambatan program kemandirian untuk bantuan tunai klien di Ohio. Kami menemukan tiga identitas berbeda manajer dan tanggapan terhadap tantangan dan hambatan. Pertama, Watkins-Hayes (2009), menemukan bahwa manajer pekerjaan sosial diidentifikasi lebih holistik dalam pendekatan mereka dan fokus pada hambatan struktural untuk selfsufficiency. Tipe kedua manajer efficiency engineer jauh lebih hati-hati dan fokus pada hambatan individu klien. Ketiga, mirip dengan penelitian (Taylor dan Seale, 2013) yang ada, menemukan dukungan untuk kategori lain manajer 'konflik' yang membahas kedua hambatan individu-tingkat struktural dan self-sufficiency.

2. Pengembangan Hipotesis

Telah banyak penelitian yang dilakukan untuk menentukan faktorfaktor yang mempengaruhi adopsiteknologi informasi dan komunikasi individu dalam meningkatkan kinerja tugasnya. Model Technology Acceptance Model (TAM), Brown (2002) memberikan bukti terdapat pengaruh yang kuat terhadap adopsi teknologi informasi komputer di negara-negara berkembang. Chambers dan Parker (2000) menyatakan bahwa faktor individual, yaituinovasi, pendidikan, umur, pengalaman, waktu dan ketrampilan merupakan faktor yang mempengaruhikeputusan adopsi teknologi informasi komputer oleh wirausahawan. Penelitian ini dilakukan untuk mengetahui self- sufficiency mahasiswa teknik informatika. Kedua untuk memastikanhubunganantara jenis kelamin, penghasilan, status tinggal dan usia dengan self sufficiacy.

\section{METODE RISET}

Lokasi penelitian dilakukan di STMIK AMIKOM Purwokerto yang beralamat di Jl. Let Jend. Pol. Sumarto Watumas Purwanegara Purwokerto. Sasaran penelitian adalah mahasiswa teknik informatika yang menjalankan technopreneurship. Berdasarkan informasi dari pihak STMIK Amikom Purwokerto jumlah mahasiswa yang mahasiswa teknik informatika yang menjalankan technopreneurship sebanyak84 mahasiswa. Peneliti mengestimasi tingkat kesalahan 5\%, sehingga dapat dihitung sampel minimum sebagai berikut:

$$
\begin{aligned}
& \mathrm{n}=\frac{84}{1+84(0,05)^{2}} \\
& \mathrm{n}=69,42
\end{aligned}
$$

Berdasarkan rumus slovin (Umar, 2008) di atas, ukuran sampel adalah 70 responden. Peneliti memutuskan untuk mengambil sampel sebanyak 70 responden. Skala berikut diberikan kepada 70 mahasiswa yang menjalankan technopreneurship yang dipilih untuk tujuan pengumpulan data primer untuk penelitian ini. Selfsufficiency (6 item Likert - jenis skala lima poin) yang sebagian diadaptasi dari Raskin, Robert dan Howard Terry (1988).Teknik pengumpulan data utama yang digunakan adalah kuesioner. Alat analisis yang digunakan untuk uji validitas adalah menggunakan korelasi product moment, uji reliabilitas menggunakan alpha cronbach (Sugiyono, 2009). Untuk mengetahui hubungan karakteristik individu dengan Selfsufficiencydigunakan analisis korelasi product moment (Sugiyono, 2009).

PEMBAHASAN DAN KESIMPULAN 
1. Pembahasan

Instrumenpenelitianuntukme ngukurself-

sufficiencymenggunakaninstrumen yang dikembangkanolehRaskin, Robert dan Howard Terry (1988) A principal component analysis of the narcissistic personality inventory and further evidence of

Tabel 1. Hasil Uji Validitas dan Reliabiltas Instrumen

\begin{tabular}{|c|c|c|c|c|c|c|c|c|}
\hline & & Item_1 & Item_2 & Item_3 & Item_4 & Item_5 & Item_6 & Total \\
\hline & Pearson Correlation & 1 & $464^{* *}$ & 150 & 101 &, $225^{*}$ & ,008 &, $623^{* *}$ \\
\hline Item_1 & Sig. (1-tailed) & & ,000 & , 108 & ,204 & ,031 & 475 & ,000 \\
\hline & $\mathrm{N}$ & 70 & 70 & 70 & 70 & 70 & 70 & 70 \\
\hline & Pearson Correlation & $464^{* *}$ & 1 &, $289^{* *}$ &, 139 & $289^{* *}$ & ,084 &, $699^{* *}$ \\
\hline Item_2 & Sig. (1-tailed) &, 000 & & ,008 & , 126 & ,008 & 244 & ,000 \\
\hline & $\mathrm{N}$ & 70 & 70 & 70 & 70 & 70 & 70 & 70 \\
\hline & Pearson Correlation &, 150 &, $289^{* *}$ & 1 &,- 003 &,- 040 & 072 &, $449^{* *}$ \\
\hline Item_3 & Sig. (1-tailed) & ,108 & ,008 & & ,490 & ,372 & ,277 &, 000 \\
\hline & $\mathrm{N}$ & 70 & 70 & 70 & 70 & 70 & 70 & 70 \\
\hline & Pearson Correlation & , 101 & , 139 &,- 003 & 1 & ,104 & , 143 &, $442^{* *}$ \\
\hline Item_4 & Sig. (1-tailed) & ,204 & , 126 & ,490 & & ,195 & ,119 & $\overline{0}, 000$ \\
\hline & $\mathrm{N}$ & 70 & 70 & 70 & 70 & 70 & 70 & 70 \\
\hline & Pearson Correlation &, $225^{*}$ &, $289^{* *}$ &,- 040 & , 104 & 1 &, $222^{*}$ &, $563^{* *}$ \\
\hline Item_5 & Sig. (1-tailed) & ,031 & ,008 & ,372 & , 195 & &, 032 &, 000 \\
\hline & $\mathrm{N}$ & 70 & 70 & 70 & 70 & 70 & 70 & 70 \\
\hline & Pearson Correlation & ,008 & ,084 & ,072 & , 143 &, $222^{*}$ & 1 &, $461^{* *}$ \\
\hline Item_6 & Sig. (1-tailed) & 475 & ,244 & ,277 & ,119 & ,032 & &, 000 \\
\hline & $\mathrm{N}$ & 70 & 70 & 70 & 70 & 70 & 70 & 70 \\
\hline & Pearson Correlation &, $623^{* *}$ & $699^{* * *}$ &, $449^{* *}$ &, $442^{* *}$ &, $563^{* *}$ &, $461^{* *}$ & 1 \\
\hline Total & Sig. (1-tailed) & ,000 & ,000 & ,000 & ,000 & ,000 & ,000 & \\
\hline & $\mathrm{N}$ & 70 & 70 & 70 & 70 & 70 & 70 & 70 \\
\hline & & $\mathrm{Crc}$ & ach's A & ha:, 51 & & & & \\
\hline
\end{tabular}

Survei menemukan bahwa mahasiswa yang menjalankan technopreneurship untuk yang berjenis kelamin lakilaki $(88,6$ persen) dan perempuan $(11,4$ persen) seperti yang ditunjukkan pada gambar 1. Hasil ini konsisten denganHassan \&Wafa (n.d), menyatakan bahwa adanya hubungan yang signifikan antara kecenderungan mengambil resiko (risk taking propensity) dan niat untuk menjadi seorang pengusaha, dari hasil penelitian tersebut juga its construct valdity padajournal of personality and social psycology, penelitimelakukanpengujianvalidit asterhadapenaminstrumenselfsufficiencydenganhasilsepertiditunj ukanpadatabel 1. Bahwa keenam instrumen tersebut adalah valid dan reliabel. 
Pendapat beberapa ahli lain menunjukkan bahwa wanita juga mempunyai minat untuk berwirausaha, menurut Manurung(2007) dalam buku Wanita Berbisnis Makanan, wanita sebagai individu juga mempunyai keinginan berbisnis, walau secara tradisional diharapkan mendidik anak dan mengurusi rumah tangga. Sudah bukan zamannya lagi wanita mengikuti kebiasaan tradisional seperti itu, tetapi bergerak maju, terlihat dengan banyak wanita yang memimpin bisnis besar dan juga professional ulung.

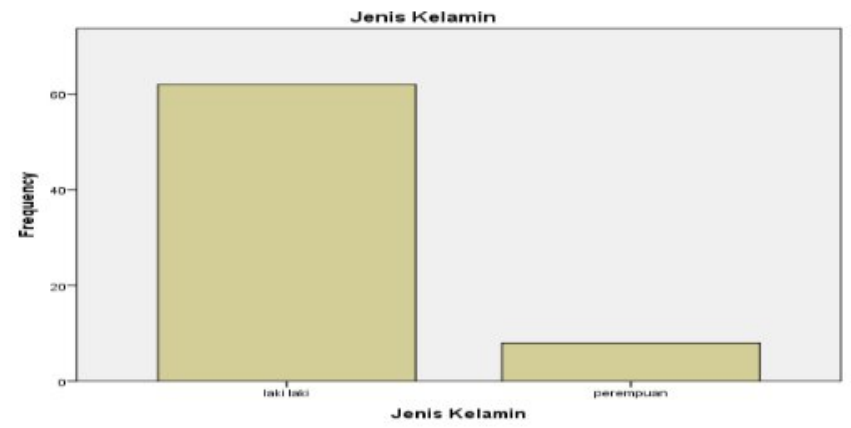

Gambar 1. Jenis kelamin mahasiswa yang menjalankan technopreneurship

Wirausaha wanita secara nyata menghadapai pesoalan yang secara umum dihadapi para pelaku wirausaha. Mereka juga harus berurusan dengan kesulitan yang berhubungan dengan peran mereka yang baru. Kurang akses mendapatkan kredit merupakan permasalahan yang sering muncul bagi wanita yang memasuki suatu bisnis. Sehingga perlu diketahui faktor- faktor yang mendorong wanita terjun ke dunia usaha. Menurut Kasmir(2013) dalam bukunya yang berjudul kewirausahaan, ada lima sebab atau cara seseorang untuk mulai merintis usahanya, yaitu 1) Faktor keluarga pengusaha; 2) Sengaja terjun menjadi pengusaha; 3) Kerjasampingan (iseng); 4) Coba-coba; 5) Terpaksa.

Tambunan (2012) dalam buku usaha mikro kecil dan menengah di Indonesia, menjelaskan bahwa faktor yang mendorong wanita untuk berwirausaha yaitu faktor yang bersifat langsung dan tidak langsung. Faktor yang bersifat langsung adalah tekanan ekonomi (keuangan) dan latar belakang social dan budaya.Di antara banyak latar belakang sosial dan budaya yang mempengaruhi keberadaan wanita pengusahaadalah agama, tingkat pendidikan formal dan keahlian, umur, etnis, dan kebiasaan. Sedangkan factor yang tidak langsung adalah kebijakan pemerintah dan stabilitas lingkungan sosial-ekonomi domestik. Namun faktor yang paling mempengaruhi wanita untuk berwirausaha adalah faktor yang bersifat langsung.

Dilihat dari jumlah penghasilan mahasiswa yang menjalankan technopreneurship cukup beragam dari yang paling rendah berpenghasilan Rp.500.000,00 per bulan sampai penghasilan tertinggi mencapai Rp.5000.000,00 per bulan, sehingga diperoleh rata-rata untuk tiap mahasiswa mempunyai penghasilan Rp. 2.090.000,00 tiap bulannya. Dari 70 responden ditemukan bahwa sebagian besar mempunyai penghasilan sebanyak Rp. 1.000.000,00 tiap bulan mencapai 22,9 persen, dan hanya sedikit yang 
berpenghasilan mencapai Rp.4.000.000,00 tiap bulanya (1,4 persen) seperti ditunjukkan pada gambar 2.

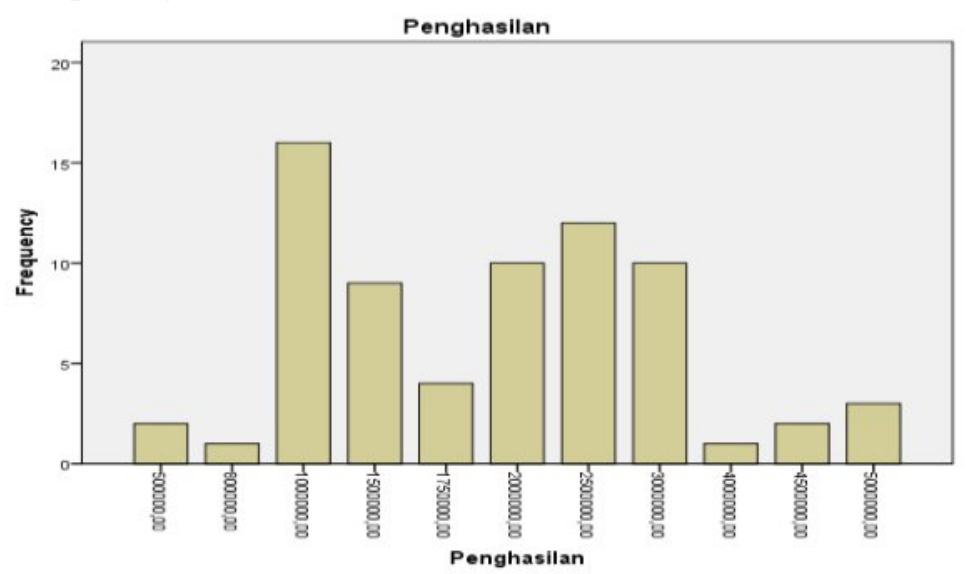

Gambar 2. Penghasilan mahasiswayang menjalankan technopreneurship

Untuk status tinggal mahasiswa yang menjalankan technopreneurship sebagian besar tinggal di tempat kos (90,0 persen) dan hanya sebagian kecil saja yang tinggal bersama orang tua (10,0 persen), seperti ditunjukkan pada gambar3. Hal ini menunjukkan bahwa lingkungan luar seperti teman dan pengetahuan yang di dapat diperkuliahan mempengaruhi technopreneurship, Izedonmi\&Chinonnye, (2010) menyatakan bahwa lingkunganmasyarakat yang merupakan lingkungan di luar lingkungan keluarga baik di kawasan tempat tinggalnya maupun dikawasan lain mempengaruhi minat berwirausaha.

Berdasarkan hasil dari penelitian Hermina, Novieyana \& Zain (2011), dukungan keluarga merupakan faktor membentuk minat berwirausaha dan kondisi peluang bisnis sangat mendukung minat untuk menjadi wirausaha di mana kodisi peluang bisnis dapat dikategorikan ke dalam faktor creativity. Hal ini juga didukung oleh hasil dari penelitian Wibowo (2011), bahwa faktor pembelajaran di lingkungan sekolah memiliki pengaruh paling tinggi terhadap minat mahasiswa.

Untuk status tinggal mahasiswa, ada yang bertempat tinggal bersama orang tua dan banyak pula yang tinggal di tempat kos. Mahasiswa yang menempati kos sebagian besar berasal dari kota sekitar yang berjarak lebih dari $40 \mathrm{~km}$ dari kampus. Hasil selengkapnya dapat dilihat pada gambar berikut.

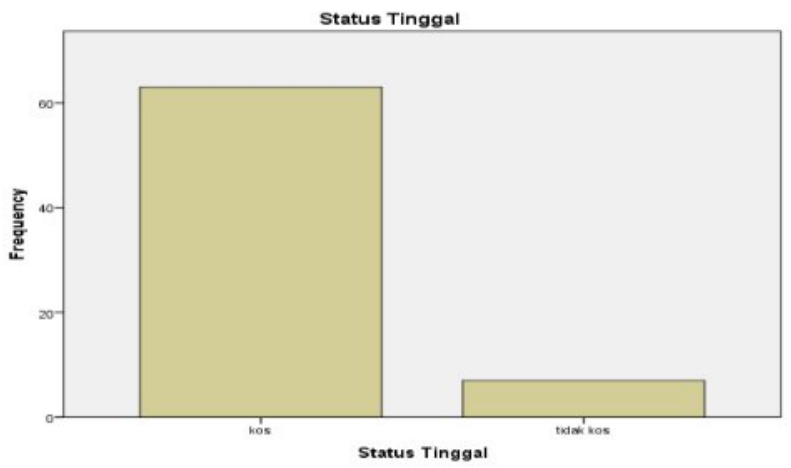

Gambar 3. Status tinggal mahasiswayang menjalankan technopreneurship 
Jenis usaha yang dijalankan oleh mahasiswa yang menjalankan technopreneurship cukup beragam, untuk yang bergerak di bidang pembuatan animasi mencapai 10 responden (14,3persen), untuk yang bergerak di bidang pembuatan aplikasi desktop mencapai 31 responden (44,3 persen), untuk yang bergerak di pembuatan WEB mencapai 19 responden (27,1 persen), yang bergerak di bidang pembuatan game mencapai 10 responden (14,3 persen), seperti ditunjukkan pada gambar 4. Sebagian besar usaha yang dikembangkan oleh mahasiswa adalah aplikasi desktop, Desktop Based Application adalah suatu aplikasi yang dapat berjalan sendiri atau independen tanpa menggunakan browser atau koneksi Internet di suatu komputer otonom dengan operating system atau platform tertentu. Aplikasi Desktop difokuskan kepada aplikasi yang lebih independen. Akan tetapi dengan bergesernya waktu wirausaha di bidang aplikasi desktop akan bergeser ke aplikasai WEB, salah satu keunggulan kompetitif dari Aplikasi Berbasis Web adalah bahwa aplikasi tersebut ringan dan dapat diakses dengan cepat melalui browser dan koneksi internet atau intranet ke server. Ini berarti bahwa pengguna dapat mengakses data atau informasi perusahaan melalui laptop, smartphone, atau bahkan komputer PC di rumah dengan mudah.

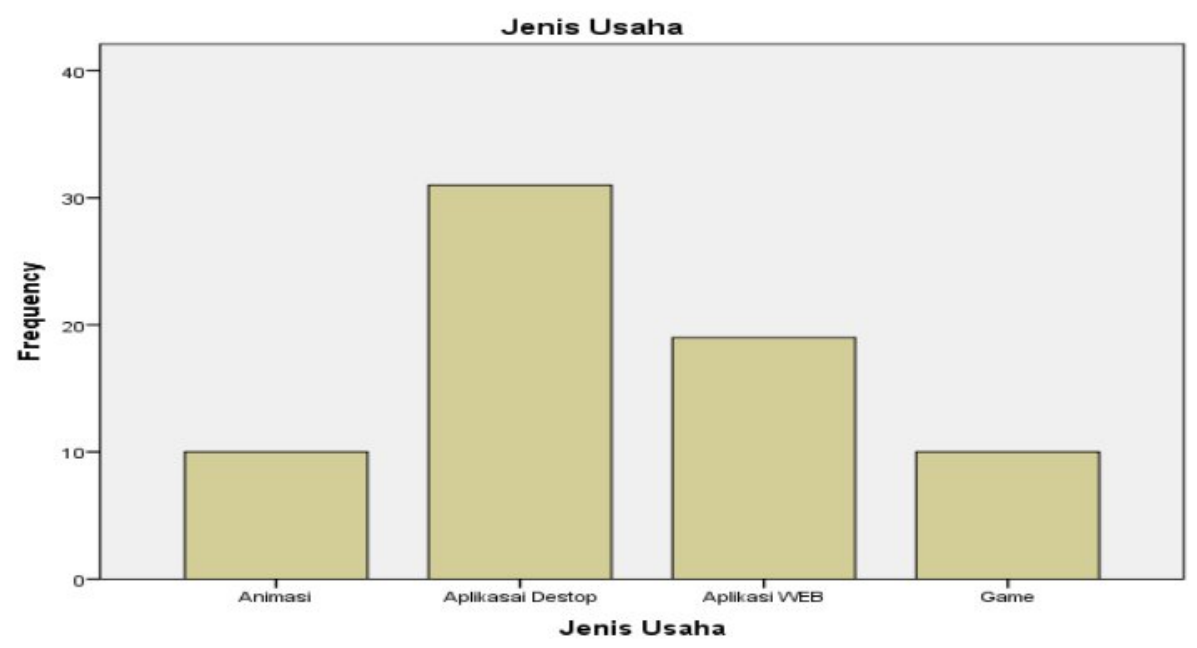

Gambar 4. Jenis usaha yang dijalankan mahasiswa technopreneurship

Untuk usia mahasiswa yang menjalankan technopreneurship antara 20 tahun (22,9 persen) sampai usia 23 tahun (1,4 persen), sebagian besar mahasiswa technopreneurship ini berusia 21 tahun (62,9 persen) seperti ditunjukkan pada gambar 5. Hal ini tidak konsisten dengan hasil penelitian Saravana Kumar \& Saravanan (2012), persentase para mahasiswa untuk berwirausaha masih relatif rendah, di mana hanya $26,8 \%$ dari mereka yang berkeinginan untuk menjadi seorang entrepreneur setelah lulus kuliah dan 29,6\% dari mereka memilih untuk bekerja, 21\% memilih untuk bekerja dan bisnis paruh waktu (part time), 15\% melanjutkan studi dan 7,6\% menggambarkan niat karirnya secara garis besar 


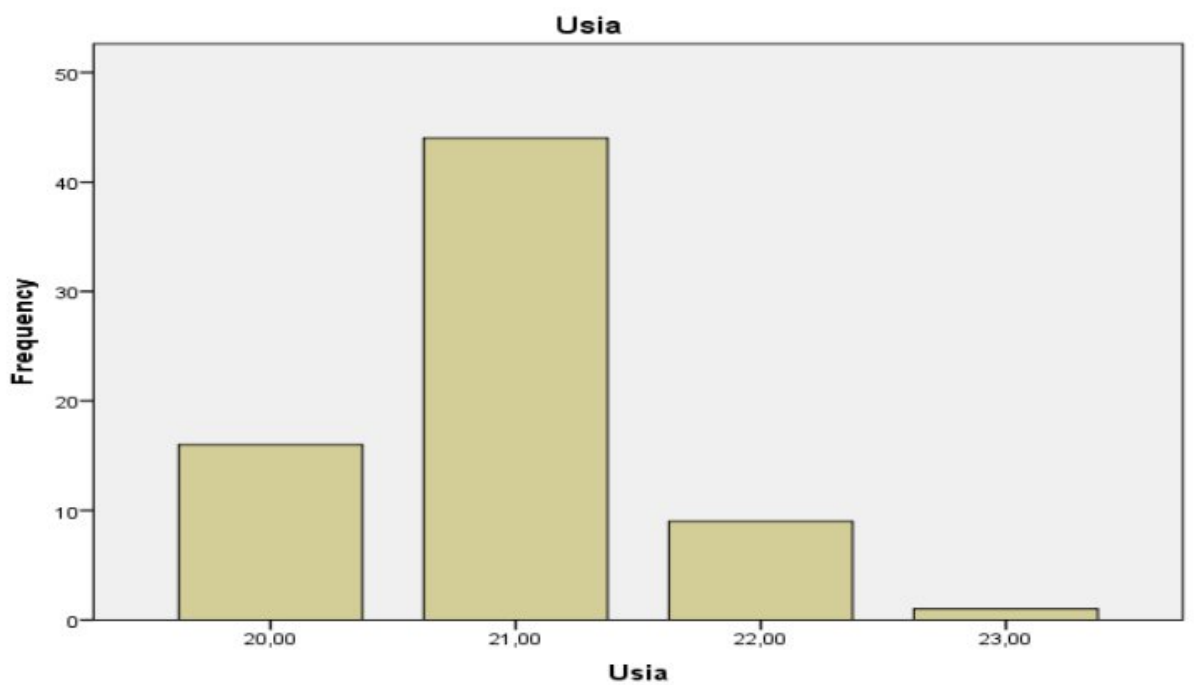

Gambar 5. Usia mahasiswa yang menjalankan technopreneurship

Hubungan antara faktor demografi seperti jenis kelamin, penghasilan, status tinggal dan usia dengan self sufficacy menunjukkan bahwa jenis kelamin mempunyai hubungan yang signifikan dengan self sufficiacy sebesar 0,388 , sedangkan faktor lain seperti penghasilan, status tinggal dan usia tidak mempunyai hubungan yang signifikan seperti ditunjukkan pada tabel 2.

Tabel 2. Correlations jenis kelamin, penghasilan, status tinggal dan usia dengan self sufficiacy

\begin{tabular}{|c|c|c|c|c|c|c|}
\hline & & $\begin{array}{c}\text { Jenis } \\
\text { Kelamin }\end{array}$ & Penghasilan & $\begin{array}{c}\text { Status } \\
\text { Tinggal }\end{array}$ & Usia & $\begin{array}{c}\text { Self } \\
\text { Sufficiacy }\end{array}$ \\
\hline Jenis & $\begin{array}{l}\text { Pearson } \\
\text { Correlation }\end{array}$ & 1 &,$- 261^{*}$ & ,030 &,- 100 &, $388^{* *}$ \\
\hline \multirow[t]{3}{*}{ Kelamin } & Sig. (2-tailed) & & ,029 & ,806 & ,409 & 001 \\
\hline & $\mathrm{N}$ & 70 & 70 & 70 & 70 & 70 \\
\hline & $\begin{array}{l}\text { Pearson } \\
\text { Correlation }\end{array}$ &,$- 261^{*}$ & 1 &,- 061 & ,139 & ,018 \\
\hline \multirow{2}{*}{$\begin{array}{l}\text { Penghasil } \\
\text { an }\end{array}$} & Sig. (2-tailed) & ,029 & & ,614 & ,253 & ,884 \\
\hline & $\mathrm{N}$ & 70 & 70 & 70 & 70 & 70 \\
\hline \multirow{3}{*}{$\begin{array}{l}\text { Status } \\
\text { Tinggal }\end{array}$} & $\begin{array}{l}\text { Pearson } \\
\text { Correlation }\end{array}$ & ,030 &,- 061 & 1 &, 037 &, 042 \\
\hline & Sig. (2-tailed) & ,806 & ,614 & & ,760 & ,731 \\
\hline & $\mathrm{N}$ & 70 & 70 & 70 & 70 & 70 \\
\hline \multirow{3}{*}{ Usia } & $\begin{array}{l}\text { Pearson } \\
\text { Correlation }\end{array}$ &,- 100 & ,139 & ,037 & 1 &,- 190 \\
\hline & Sig. (2-tailed) & ,409 & ,253 & ,760 & & , 116 \\
\hline & $\mathrm{N}$ & 70 & 70 & 70 & 70 & 70 \\
\hline \multirow{3}{*}{$\begin{array}{l}\text { Self } \\
\text { Sufficiac } \\
\text { y }\end{array}$} & $\begin{array}{l}\text { Pearson } \\
\text { Correlation }\end{array}$ &, $388^{* *}$ & ,018 & ,042 &,- 190 & 1 \\
\hline & Sig. (2-tailed) & 001 & ,884 &, 731 &, 116 & \\
\hline & $\mathrm{N}$ & 70 & 70 & 70 & 70 & 70 \\
\hline
\end{tabular}


2. Kesimpulan

Penelitian ini merupakan studi kasus empiris mengeksplorasi hubungan antara perilaku technopreneurship mahasiswa teknik informatika dan self sufficiacy dengan menggunakan berbagai faktor demografi seperti jenis kelamin, penghasilan, status tinggal dan usia. Beberapa temuan menarik dicatat. Pertama, alasan utama untuk berwirausaha di bidang teknologi informasi adalah untuk memenuhi kebutuhan, sementara sebagian besar mahasiswa yang melakukan kegiatan technopreneur berusia 21 tahun, mereka menggunakan ilmu yang didapat diperkuliahan sebagai modal dalam menjalankan usahanya. Kedua bahwa jenis kelamin mahasiswa technopreneur berhubungan dengan self sufficiacy, mereka lebih senang untuk tidak menggantungkan diri pada orang lain, suka mengambil tanggung jawab untuk membuat keputusan, merasa lebih kompeten dari orang lain, merasa dapat hidup dengan sarana yang sesuai dengan keinginan, selalu mengetahui apa yang harus mereka lakukan dan mereka merasa orang yang hebat.

Sikap atau kesiapan mental mahasiswa teknik informatika untuk terjun memulai usaha baru mendasari munculnya minat technopreneurship. Menurut Slameto (2003) sikap merupakan sesuatu yang dipelajari dan bagaimana individu bereaksi terhadap situasi serta menentukan apa yang dicari individu dalam kehidupan. Kepribadian seseorang akan selalu berpengaruh atau dipengaruhi oleh faktor internal dan eksternal. Salah satu faktor internal yang menjadi dorongan seseorang untuk berwirausaha adalah sikap mandiri (Kuckertz\& Wagner, 2010).

Selain itu, tumbuhnya minat technopreneurship juga tidak lepas dari pengaruh factor ekstrinsik. Faktor ekstrinsik adalah faktor-faktor yang mempengaruhi individu karena pengaruh rangsangan dari luar. Faktor-faktor ekstrinsik yang mempengaruhi intense technopreneurship antara lain: lingkungan keluarga, lingkungan masyarakat, peluang, pendidikan/pengetahuan. Sesuai dengan hasil penelitian Pihie (2009); Bagheri dan Pihie (2009), minat berwirausaha akan terbentuk apabila keluarga memberikan pengaruh positif terhadap minat tersebut, karena sikap dan aktivitas sesame anggota keluarga saling mempengaruhi baik secara langsung maupun tidak langsung. Seharusnya orang tua yang berwirausaha dalam bidang tertentu dapat menimbulkan minat anaknya untuk berwirausaha dalam yang sama pula.

Kemudian lingkungan luar yang mempengaruhi minat berwirausahaantara lain lingkungan masyarakat yang merupakan lingkungan di luar lingkungan keluarga baik di kawasan tempat tinggalnya maupun di kawasan lain (Izedonmi\&Chinonnye, 2010). Lingkungan kampus yang dapat mempengaruhi minat technopreneurship dalam bidang teknologi informatika antara lain dosen, teman dan pengetahuan yang di dapat saat kuliah.

\section{IMPLIKASI DAN KETERBATASAN}

Peneliti selanjutnya bisa membahas tentang self-efficacy, self-efficacy adalah pertimbangan subjektif individu terhadap kemampuannya untuk menyusun tindakan yang dibutuhkan untuk menyelesaikan tugas-tugas khusus yang dihadapi. Self-efficacy merupakan salah satu faktor personal yang menjadi 
perantara atau mediator dalam interaksi antara faktor perilaku dan faktor lingkungan. Self-efficacy merupakan masalah persepsi subyektif artinya selfefficacy tidak selalu menggambarkan kemampuan yang sebenarnya, tetapi terkait dengan keyakinan yang dimiliki individu. Menurut Albert self-efficacy merupakan keyakinan bahwa seseorang dapat menguasai situasi dan memproduksi hal positif (Albert, 1986). Teori self efficacy yang disebut juga sebagai teori kognitif social yaitu teori umum yang berlaku untuk berbagai jenis perilaku manusia dalam kehidupan sehari-hari termasuk perilaku informasi. Kekuatan utama dari teori ini berdasarkan penelitian perilaku penemuan informasi dapat diterapkan ke berbagai konteks dan pengaturan, terutama dalam perilaku penemuan informasi sehari-hari. Dengan demikian, teori ini dapat membantu menggambarkan suatu perilaku informasi manusia.

\section{DAFTAR REFERENSI}

Bagheri, A \& Pihie, Z. A. L. (2009). An Exploratory Study of Entrepreneurial Leadership Development of University Students. European Journal of Social Sciences. Vol. 11, No. 1, pp: 177-190

Bogue Donald. J, (1969). Bogue, Donald, J., Principle of Demography. New York : John Wiley and Son, Inc

Bandura, Albert., (1986). Social foundations thought and action a social cognitive and theory practice. Hall inc. New Jersey

Baumol, W. J., Litan, R. E., \& Schramm, C. J. (2007). Sustaining entrepreneurial capitalism. Capitalism and Society, 2(2) Article 1. Available at:http://www.bepress.com/cas /vol2/iss2/art1

Brown, I. T. J. (2002). Individual and technological factors affecting perceived ease of use of web-basedlearning technologies in developing country. The Electronic Journal on Information Systems inDeveloping Countries 9 (5): 115

Cattell, H. E. P., \& Mead, A. D. (2008), The Sixteen Personality Factor Questionnaire (16PF), dalam The Sage Handbook of Personality Theory and Assessment: Personality measurement and testing. (vol. 02)., eds. Boyle, I.G. \& Matthews,G. \& D. H. Saklofske, Sage Publications, Los Angeles, p. 135-178

Chambers, T. A., dan C. M. Parker. (2000). Factors motivating and inhibitting the use of web commerce by rural small business. Working Paper. School of Management System. Deakin University: Burwood

Hassan, R.A. \& Wafa, S.A. (n.d). Predictors towards entrepreneurial intention: A malaysian case study. Asian Journal of Business and Management Sciences, 1(11), 01-10.

Hermina, U.N., Novieyana, S. \& Zain, D. (2011). Pengaruh Mata Kuliah Kewirausahaan Terhadap Minat Mahasiswa Menjadi Wirausaha. Jurnal Eksos, 7(2), 130-141

Hong Philip Young P., Vamadu A. Sheriff, Sandra R. Naeger. (2009). A Bottomup Definition of Self-sufficiency Voices from Low-income Jobseekers. Qualitative Social Work 8 (3)

Indonesia. Kementerian Koperasi dan Usaha Kecil dan Menengah Republik Indonesia. (2012). EntrepreneurSelalu Siap Hadapi Perubahan. Retrieved Februari11, 2015, 
fromhttp://www.depkop.go.id/index.php?option=com_content\&view=articl e\&id=885:menkop-ukm-entrepeneur-selalu-siap-hadapiperubahan \&catid $=50$ :bind-berita\&Itemid $=97$

Izedonmi, P. F \& Chinonnye, O. (2010). The Effect of Entreprneurship Education onStudents Entrepreneurial Intentions. Global Journal of Management and Business Research. Vol. 10, issue 6, pp: 49-59

Manurung Adler Haymas. (2007).Wanita Berbisnis UKM Makanan. Jakarta: PT.KompasMedia Nusantara

Notoatmodjo Soekidjo. 2010. Pengembangan Sumber Daya Manusia. Jakarta: Rineka Cipta

Raskin, Robert dan Howard Terry. (1988). A Principal Component Analysis of The Narcissistic Personality Inventory and Further Evidence of its Construct Valdity. Journal of Personality and Social Psycology. 54 (May), 890-902

Saravanakumar, M. \& Saravanan, S. (2012). Entrepreneurship Education Shaping Entrepreneurial Intention. European Journal of Social Sciences, 33(2), 317323

Siagian, Sondang (2008). Manajemen Sumber Daya Manusia (cetakan 15). Jakarta: Bumi Aksara

Soeryanto Eddy. (2009). Entrpreneurship: Menjadi Pebisnis Ulung. Jakarta: Elex Media Komputindo

Sugiyono.(2009).Statistik Untuk Penelitian.Bandung:CV Alfa Beta

Tambunan Tulus. (2012). Usaha Mikro Kecil dan Menengah di Indonesia Isu-Isu Penting. Jakarta: LP3ES

Taylor Tiffany, Christi L. Gross, Jackuelyn Towne-Roese. (2015). Program Barriers and Challengesto Self-Sufficiency: A QualitativeAnalysis of Ohio Welfare-to-WorkProgram Manager Identity. Critical Sociology1 17

Taylor T and Seale E (2013) Implementing welfare-to-work: Program managers identities and service deliveryin North Carolina. Sociological Focus 46(4): 295313.

Umar Husein. (2008). Desain Penelitian MSDM dan Perilaku Karyawan. Seri Desain Penelitian Bisnis No 1. Jakarta: PT Rajagrafindo Persada

Vohs, K. D., et al. (2008). Making Choices Impairs Subsequent Self-Control: A Limited-Resource Account of Decision Making, Regulation, and Active Initiative. J Pers Soc Psychol, Vol. 94, No. 5, pp. 88398

Watkins-Hayes C (2009) The New Welfare Bureaucrats: Entanglements of Race, Class, and Policy Reform. Chicago, IL: University of Chicago Press

Wibowo, M. (2011). Pembelajaran Kewirausahaan Dan Minat Wirausaha Lulusan SMK. Eksplanasi, 6(2), 109-122

Zimmerer, Scarborough. (2008). Kewirausahaan dan Manajemen Usaha Kecil. Jakarta: Edisi Kelima, Salemba Empat 